\title{
The accuracy characteristics of control over productivity of liquid, oil and gas on wells
}

\author{
H.J. Jafarov, S.M. Abbasova \\ Azerbaijan State University of Oil and Industry, Azadlig Avenue, 20, AZ1010, Baku, Azerbaijan \\ abbasovasakina@rambler.ru
}

\section{Abstract}

World practice shows that due to improper management of the oil production process, up to $40 \%$ of the reserves of oil fields identified during exploration are mined. One of the main reasons for this is an incorrect quantitative assessment of the accuracy characteristics of the measurement information obtained in measuring the productivity of oil wells used in taking management decisions. The accuracy characteristic of the measuring information depends on the error of the measuring instruments used and, at the same time, on the errors arising from the influence of other factors on the measurement. Among the operational measuring devices of the yield of oil wells, the type group measurement device "Trap" is the most reliable and rational.

Considering that the algorithms for controlling of the yield over gas, over oil and over the general liquid of oil wells contain many periodically measured parameters and tabulated data, the measurement and determination of which is influenced by a sufficient number of factors, then as an accuracy characteristics of measurement of the yield it is expedient to use the uncertainty of measuring the yield for separate components. Determining of the uncertainty of measuring the yield of oil wells along with the improvement of measurement quality leads to an effective management of well operation.

Keywords: yield, measurement, correlation, distribution function, uncertainty.

\section{Introduction}

Researches of technical means used to measure oil wells production $[1,2]$ show that, the most perfect among them is "Trap" type Group Measurement Device (hereinafter GMD) [3]. Unlike others, this device allows measuring the production of oil wells not only on different components, but also capable of carrying out these measurement operations for different gas-fertilization and irrigation coefficient wells [3]. Therefore, "Trap" type GMD is preferred in the article.

Uncertainty of measurement of oil wells production on gas, total liquid (water + oil) and oil through abovesaid GMD is one of the most accurate indications that quantitatively reflects the accuracy of the measurement results [4]. The urgency of solving the problem in the article does not raise any doubts taking into account that current results of measuring wells for operative decisions taken to manage wells management are the most important data and that the accuracy of the decisions has a direct impact on the accuracy of the measurement results.

\section{Formulation of the problem}

Uncertainty of measurement is the parameter, which is associated with its results and characterizing the numerical scattering [4]. A measurement model should be available for its determination.
Daily extraction on separate components of oil wells production by "Trap" type measuring models with GMD was given in [5]. For simplicity, if we consider that daily gas extraction $\left(V_{\mathrm{g}}\right)$ is same in the measurement model was given in [5] during the process of gathering current values of all input parameters of the well production in the GMD separator, then that model can be written as follows:

$$
V_{\mathrm{g}}=24 \cdot 0,2109 \cdot \alpha \cdot \varepsilon \cdot k_{\mathrm{t}}^{2} \cdot d_{20}^{2} \cdot \sqrt{\frac{\rho \cdot \Delta \rho}{\rho_{\mathrm{n}} \cdot T \cdot K}},
$$

where $\alpha, \varepsilon, k_{\mathrm{t}}, d_{20}, P, \Delta P, \rho_{\mathrm{n}}, T$ and $K$ are input parameters of model, accordingly: the coefficient of flow rate, coefficient of correction of the measured medium (gas) expansion, the diameter of the corrugation hole (diaphragm) at $20{ }^{\circ} \mathrm{C} \mathrm{mm}$; absolute pressure before the narrowing structure of the measured environment, $\mathrm{kgf} / \mathrm{cm}^{2}$; the difference in pressure in the narrowing structure, $\mathrm{kgf} / \mathrm{m}^{2}$; the density of the measured medium in normal conditions, $\mathrm{kg} / \mathrm{m}^{3}$; temperature, $K$, and compression coefficient of the measured medium.

Taking into account that daily general liquid and oil extraction from wells in "Trap" type GMD measurement models after a period of multiple extraction of the well product in the height of the water column that emerges there are in variable level slammer at least $100 \mathrm{~mm}$ from the zero yoke level, while the height of the oil column at least $400 \mathrm{~mm}$ above that level and taking into account 
that the conditions of $\tau_{\mathrm{c}, \gamma}<\tau_{\text {tot }}<\tau_{\mathrm{c}, \gamma+1}, \tau_{\mathrm{c}, \gamma}<\tau_{\mathrm{sn}}<\tau_{\mathrm{c}, \gamma+1}$ will be met, measurement models with GMD type "Trap" of the yield of the well for total liquid $\left(V_{\text {tot }}\right)$ and oil $\left(V_{\mathrm{n}}\right)$ can be written in the following general ways [6]:

$$
\begin{aligned}
V_{\mathrm{tot}} & =\frac{24}{\tau_{1}} \cdot\left[V_{\mathrm{c}, \gamma}+\left(\tau_{\mathrm{tot}}-\tau_{\mathrm{c}, \gamma}\right) \cdot \frac{V_{\mathrm{c}, \gamma+1}-V_{\mathrm{c}, \gamma}}{\tau_{\mathrm{c}, \gamma+1}-\tau_{\mathrm{c}, \gamma}}\right] ; \\
V_{n} & =\frac{24}{\tau_{1}} \cdot\left\{\left[V_{\mathrm{c}, \gamma}+\left(\tau_{\mathrm{tot}}-\tau_{\mathrm{c}, \gamma}\right) \cdot \frac{V_{\mathrm{c}, \gamma+1}-V_{\mathrm{c}, \gamma}}{\tau_{\mathrm{c}, \gamma+1}-\tau_{\mathrm{c}, \gamma}}\right]-\right. \\
- & {\left.\left[V_{\mathrm{c}, \gamma^{\prime}}+\left(\tau_{\mathrm{cn}}-\tau_{\mathrm{c}, \gamma^{\prime}}\right) \cdot \frac{V_{\mathrm{c}, \gamma^{\prime}+1}-V_{\mathrm{c}, \gamma^{\prime}}}{\tau_{\mathrm{c}, \gamma^{\prime}+1}-\tau_{\mathrm{c}, \gamma^{\prime}}}\right]\right\} }
\end{aligned}
$$

where $\tau_{1}, \tau_{\mathrm{tot}}, \tau_{\mathrm{sn}}, V_{\mathrm{c}, \gamma}\left(V_{\mathrm{c}, \gamma^{\prime}}\right), V_{\mathrm{c}, \gamma+1}\left(V_{\mathrm{c}, \gamma^{\prime}+1}\right), \tau_{\mathrm{c}, \gamma}\left(\tau_{\mathrm{c}, \gamma^{\prime}}\right), \tau_{\mathrm{c}, \gamma+1}$, $\left(\tau_{c, \gamma^{\prime}+1}\right)$ are input parameters of models, $\tau_{1}$ - the duration of accumulation of the well product in separator, $\tau_{\text {tot }}-$ after separating the components of the well production, the time period of movement from zero yoke level on variable level slammer indicator GMD up to total fluid (floating in the oil) level in the separator, $\tau_{\mathrm{sn}}-$ the time period of movement from zero yoke level on variable level slammer indicator up to water (water-oil separation-floating in the oil) level in the separator, $\gamma\left(\gamma^{\prime}\right)$, $\gamma+1\left(\gamma^{\prime}+1\right)$ - the sequence of two consecutive lines in the rank table $[5,6]$ designed with the help of technical dimensions (standard capacity) of the GMD and variable level slammer, $V_{\mathrm{c}, \gamma}\left(V_{\mathrm{c}, \gamma^{\prime}}\right), V_{\mathrm{c}, \gamma+1}\left(V_{\mathrm{c}, \gamma^{\prime}+1}\right)-$ table values for the separators that correspond to those rows, $\tau_{c, \gamma}\left(\tau_{c, \gamma^{\prime}}\right), \tau_{c, \gamma+1},\left(\tau_{c, \gamma^{\prime}+1}\right)$ - the time period of movement from zero yoke level on variable level slammer indicator of water level up to fluid level forming the capability of the separator to match those strings.

As can be seen from (1) - (3), uncertainty of measurement of oil wells production on gas, total li- quid (water + oil) and oil through "Trap" type GMD is total uncertainty depending on the standard uncertainties of the input parameters included in appropriate measurement models [4]. To set uncertainty of input parameters as $B$ type standard uncertainty in order not to be exaggerated (i. e. to avoid having a small value if it can be bigger than the numerical value) in calculating numerical estimates of total uncertainties and this time it is more appropriate to consider the results of observation in the measurement of those parameters.

\section{Solution methods}

Given that the input parameters included in the model (1) are not dependent on each other (correlation), we can define the standard uncertainty of the gas production output for the wells by the following formula

$$
\begin{gathered}
U_{\mathrm{c}}\left(V_{\mathrm{q}}\right)=\sqrt{\sum_{\mathrm{i}=1}^{8} A_{\mathrm{i}}^{2} \cdot U^{2}\left(x_{\mathrm{i}}\right)}, \\
\text { where } A_{\mathrm{i}}=\frac{d V_{\mathrm{q}}}{d x_{\mathrm{i}}}
\end{gathered}
$$

is the partial derivative with respect to argument $x_{\mathrm{i}}$ of the function (1) - the sensitivity coefficient; $U\left(x_{\mathrm{i}}\right)$ is $x_{\mathrm{i}}$ $B$ type standard uncertainty of measuring the argument, $x_{1}=\alpha, x_{2}==\varepsilon, x_{3}=d_{20}, x_{4}=P, x_{5}=\Delta P, x_{6}=\rho_{\mathrm{n}}, x_{7}=T, x_{8}=k$.

In order to determine the extended uncertainties with a confidence probability of $99 \%$ of the input parameters increasing their coverage coefficient by 2.58 , corresponding to this probability [4], it is eliminated the opportunity of the above-mentioned exaggeration. Taking into account the above and according to [7], extended uncertainties of the input parameters included in equation (1) can be calculated from the corresponding formulas:

$$
\begin{aligned}
& U(\alpha)=2,58 \cdot \alpha \cdot \frac{\left\{0,3^{2}+2 \cdot \sigma_{\mathrm{d}}\left[1+\frac{\left(\frac{d}{D}\right)^{2}}{\alpha}\right]+\sigma_{\mathrm{D}} \cdot \frac{\left(\frac{d}{D}\right)^{2}}{\alpha}\right\}^{0,5}}{100} \% \\
& U(\varepsilon)=2,58 \cdot \varepsilon \cdot \frac{\left\{\frac{1-\varepsilon}{\varepsilon}\left[\left(\frac{2 \Delta P}{P}\right)^{2}+\sigma_{\Delta \mathrm{P}}^{2}+\sigma_{\mathrm{P}}^{2}\right]^{0,5}+4 \frac{\Delta P}{P}\right\}_{\%}}{100} \% \\
& U\left(d_{20}\right)=2,58 \cdot d_{20} \cdot \frac{\sigma_{\mathrm{d}}}{100} \% \text {; } \\
& U(P)=2,58 \cdot P \cdot \frac{\left[\left(\frac{50 \Delta P_{\mathrm{b}}}{P}\right)^{2}+\left(0,5 \cdot \frac{P_{\mathrm{h}}}{P} \cdot S_{\mathrm{p}}\right)^{2}\right]^{0,5}}{100} \%
\end{aligned}
$$




$$
\begin{gathered}
U(\Delta P)=2,58 \cdot \Delta P \cdot \frac{0,5 \cdot \frac{\Delta P_{\mathrm{h}}}{\Delta P} \cdot S_{\Delta \mathrm{P}}}{100} \% ; \\
U\left(\rho_{\mathrm{n}}\right)=2,58 \cdot \rho \cdot \frac{\left\{\frac{1}{\rho} \cdot\left[\sum_{\mathrm{j}=1}^{6} N_{\mathrm{j}}^{2} \cdot\left(50^{2} \cdot \frac{\Delta \rho_{\mathrm{j}}^{2}}{\rho_{\mathrm{j}}^{2}}+\sigma_{\mathrm{N}_{\mathrm{j}}}^{2}\right)\right]^{0,5}\right.}{100} \% ; \\
U(T)=2,58 \cdot T \cdot 0,5 \cdot \frac{N_{\mathrm{t}}}{273,15+t} \cdot \frac{S_{\mathrm{t}}}{100} \% ; \\
U(k)=2,58 \cdot k \cdot \frac{\left[(1-k)^{2} \cdot\left(\sigma_{\mathrm{P}}^{2}+16 \sigma_{\mathrm{T}}^{2}+4 \sigma_{\rho_{\mathrm{n}}}^{2}+0,04 \sigma_{\mathrm{N}_{\mathrm{N}_{2}}}^{2}+0,003 \sigma_{\mathrm{N}_{\mathrm{CO}_{2}}}^{2}\right)+\sigma_{\mathrm{k}_{\mathrm{tab} .}}^{2}\right]^{0,5}}{100} \% .
\end{gathered}
$$

Within given symbols in formulas (5) - (12), $\alpha, \varepsilon, d_{20}, P, \Delta P, \rho, T, k$ are the nominal values of the corresponding input parameters, $\sigma_{\mathrm{d}}, \sigma_{\mathrm{D}}-$ the permissible root mean square errors of measurement, respectively, of the diameter of the orifice plate (diaphragm) $d$ and the internal diameter of the pipe $D$ inside which it is installed, $\Delta P_{\mathrm{b}}-$ absolute maximum error of barometric pressure measurement, $P_{\mathrm{h}}-$ upper measurement threshold of the measuring instrument for medium (gas) pressure (SAPFIR-22DI) and $S_{\mathrm{p}}$ - its class of accuracy, $\Delta P_{\mathrm{h}}-$ upper measurement threshold of the measuring instrument for the pressure difference (SAPFIR-22DI) generated in the orifice plate and $S_{\triangle \mathrm{P}}-$ its class of accuracy, $N_{\mathrm{j}}-$ the concentration of the $\mathrm{j}$ component (methane, ethane, propane, butane, nitrogen or $\mathrm{CO}_{2}$ ) forming the gas, $\rho_{\mathrm{j}}-$ half of the final figure of the table density value of the given quantity in the normal conditions, $N_{\mathrm{t}}-$ measurement range of the measuring instrument (TSM) of medium temperature before the orifice plate, $t-$ its indication, $\mathrm{S}_{\mathrm{t}}-$ accuracy class,

$$
\begin{gathered}
\sigma_{\mathrm{P}}=\left[\left(\frac{50 \cdot \Delta P_{\mathrm{b}}}{P}\right)^{2}+\left(0,5 \cdot \frac{P_{\mathrm{h}}}{P} \cdot S_{\mathrm{P}}\right)^{2}\right]^{0,5}, \\
\sigma_{\mathrm{T}}=0,5 \cdot \frac{N_{\mathrm{t}}}{273,15+t} \cdot S_{\mathrm{t}}, \\
\sigma_{\rho_{\mathrm{n}}}=\frac{1}{\rho} \cdot\left[\sum_{\mathrm{j}=1}^{6} N_{\mathrm{j}}^{2} \cdot\left(50^{2} \cdot \frac{\Delta \rho_{\mathrm{j}}^{2}}{\rho_{\mathrm{j}}^{2}}+\sigma_{\mathrm{N}_{\mathrm{j}}}^{2}\right)\right]^{0,5},
\end{gathered}
$$

$\sigma_{\mathrm{N}_{2}}, \sigma_{\mathrm{N}_{\mathrm{CO}_{2}}}-$ root mean square errors, respectively, of the measurement of pressure, temperature, gas density, determination of molar concentrations of nitrogen and $\mathrm{CO}_{2}$ in its composition, $\sigma_{\mathrm{k}_{\mathrm{tab}}}$ is the table value of the gas compression ratio [7].

If the nominal values shown in the formulas for calculating the uncertainties of the input parameters of the model (1) and their measurement (5) - (12) of other parameters are taken as $\alpha=1,002 ; d_{20}=45 \mathrm{~mm}$; $D=100 \mathrm{~mm} ; \varepsilon=0,950 ; P=2,2332 \mathrm{kgf} / \mathrm{cm}^{2} ; \Delta P=$ $=6300 \mathrm{kgf} / \mathrm{cm}^{2} ; \rho=0,7224 \mathrm{~kg} / \mathrm{m}^{3} ; T=301,15 \mathrm{~K}$; $k=1,0 ; \sigma_{\mathrm{k}_{\text {tab. }}}=0,25 ; S_{\mathrm{P}}=1,0 ; P_{\mathrm{h}}=2,5 \mathrm{kgf} / \mathrm{cm}^{2} ;$
$P_{\mathrm{b}}=1,0332 \mathrm{kgf} / \mathrm{cm}^{2} ; S_{\Delta \mathrm{P}}=1,0 ; \Delta P_{\mathrm{h}}=2500 \mathrm{kgf} / \mathrm{m}^{2} ; N_{\mathrm{t}}=$ $=373,15 \mathrm{~K} ; S_{\mathrm{t}}=1,0 ; N_{1}=0,86 ; N_{2}=0,10 ; N_{3}=0,02$; $N_{4}=0,01 ; N_{5}=N_{\mathrm{N}_{2}}=0,006 ; N_{6}=N_{c o_{2}}=0,004$;

$$
\begin{aligned}
& 50 \cdot \frac{\Delta \rho_{1}}{\rho_{1}}=0,0004 \% ; 50 \cdot \frac{\Delta \rho_{2}}{\rho_{2}}=0,0002 \% ; \\
& 50 \cdot \frac{\Delta \rho_{3}}{\rho_{3}}=0,0001 \% ; 50 \cdot \frac{\Delta \rho_{4}}{\rho_{4}}=0,0007 \% ; \\
& 50 \cdot \frac{\Delta \rho_{5}}{\rho_{5}}=0,002 \% ; 50 \cdot \frac{\Delta \rho_{6}}{\rho_{6}}=0,0001 \%,
\end{aligned}
$$

then numerical estimates of the uncertainties calculated by (5) - (12) formulas will be: $U(\alpha)=0,0032 ; U(\varepsilon)=$ $=0,00034 ; U\left(d_{20}\right)=0,023 \mathrm{~mm} ; U(P)=0,015 \mathrm{kgf} / \mathrm{cm}^{2}$; $U(\Delta P)=0,126 \mathrm{kgf} / \mathrm{m}^{2} ; U\left(\rho_{\mathrm{n}}\right)=0,0016 \mathrm{~kg} / \mathrm{m}^{3} ; U(T)=$ $=1,57 \mathrm{~K} ; U(k)=0,00645$. However, to calculate the standard combined uncertainty of the gas production wells by the formula (4), the sensitivity ratios $A_{\mathrm{i}}$ must be determined by formula (1) and their numerical values must be found. Table 1 below summarizes calculation formulas for $A_{\mathrm{i}}$ and their estimates.

Thus, substituting the numerical values obtained from the calculation of standard uncertainties of type B of the input parameters and the corresponding sensitivity coefficients from Table 1 into the formula (4), the numerical value of the combined standard uncertainty of the well flow rate measurement for gas was determined $-U_{\mathrm{c}}\left(V_{\mathrm{q}}\right)=625,65 \mathrm{~m}^{3} /$ day. Given that current values for gas can be determined [6] by applying nearly with an infinite number to $P, \Delta P, \rho, T$ transmitters included into the model (1) during that time and by considering enough more time $\left(\tau_{1}\right.$ is usually not less than 5 minutes) on the duration of filling the GMD separator with certain product of well, then the expanded uncertainty will be as follows since the coverage factor is equal to 3,00 [4] when effective degree of freedom $v_{\mathrm{s}}=\infty$, taking confidence probability of $99 \%$ $U_{\mathrm{V}_{\mathrm{g}}}=k_{\mathrm{cf}} \cdot U_{\mathrm{c}}\left(V_{\mathrm{g}}\right)=3,00 \cdot 625,65=1876,95 \mathrm{~m}^{3} /$ day.

The numerical value obtained from gas extraction of the oil well in the above mentioned nominal values of the input parameters of the model (1) is $V_{\mathrm{g}}=78453,85 \mathrm{~m}^{3} /$ day. 
Table 1. Calculation of sensitivity ratios $A_{\mathrm{i}}$

\begin{tabular}{|c|c|c|}
\hline \multirow{2}{*}{$\begin{array}{l}\text { Input } \\
\text { parame- } \\
\text { ter } x_{\mathrm{i}}\end{array}$} & \multicolumn{2}{|l|}{ Sensitivity ratio $A_{i}$} \\
\hline & Calculation formula & $\begin{array}{l}\text { Numerical } \\
\text { value }\end{array}$ \\
\hline 1 & 2 & 3 \\
\hline$\alpha$ & $\frac{24 \cdot 0,2109 \cdot \varepsilon \cdot d_{20}^{2} \cdot \sqrt{P \cdot \Delta P}}{\sqrt{\rho_{\mathrm{n}} \cdot T \cdot k}}$ & 78297,26 \\
\hline$\varepsilon$ & $\frac{24 \cdot 0,2109 \cdot \alpha \cdot d_{20} \cdot \sqrt{P \cdot \Delta P}}{\sqrt{\rho_{\mathrm{n}} \cdot T \cdot k}}$ & 82582,91 \\
\hline$d_{20}$ & $\frac{24 \cdot 0,2109 \cdot \alpha \cdot \varepsilon \cdot d_{20} \cdot \sqrt{P \cdot \Delta P}}{\sqrt{\rho_{\mathrm{n}} \cdot T \cdot k}}$ & 16353,258 \\
\hline$P$ & $\frac{24 \cdot 0,2109 \cdot \alpha \cdot \varepsilon \cdot d_{20}^{2} \cdot \sqrt{\Delta P}}{2 \cdot \sqrt{P} \cdot \sqrt{\rho_{\mathrm{n}} \cdot T \cdot k}}$ & 17560,0078 \\
\hline$\Delta P$ & $\frac{24 \cdot 0,2109 \cdot \alpha \cdot \varepsilon \cdot d_{20}^{2} \sqrt{P}}{2 \cdot \sqrt{\Delta P} \cdot \sqrt{\rho_{\mathrm{n}} \cdot T \cdot k}}$ & 6,2293 \\
\hline$\rho_{\mathrm{n}}$ & $-\frac{24 \cdot 0,2109 \cdot \alpha \cdot \varepsilon \cdot d_{20}^{2} \cdot \sqrt{P \cdot \Delta P}}{2 \cdot \sqrt{\rho_{\mathrm{n}}^{3}} \cdot \sqrt{T \cdot k}}$ & $-54309,9187$ \\
\hline$T$ & $-\frac{24 \cdot 0,2109 \cdot \alpha \cdot \varepsilon \cdot d_{20}^{2} \cdot \sqrt{P \cdot \Delta P}}{2 \cdot \sqrt{T^{3}} \cdot \sqrt{\rho_{\mathrm{n}} \cdot k}}$ & $-130,2676$ \\
\hline K & $-\frac{24 \cdot 0,2109 \cdot \alpha \cdot \varepsilon \cdot d_{20}^{2} \cdot \sqrt{P \cdot \Delta P}}{2 \cdot \sqrt{k^{3}} \cdot \sqrt{\rho_{\mathrm{n}} \cdot T}}$ & $-39231,9668$ \\
\hline
\end{tabular}

Given that the input parameters included in the model (2) are non-correlated, we can define the standard combined uncertainty of the total fluid extraction of oil wells by the following formula

$$
U_{\mathrm{c}}\left(V_{\mathrm{tot}}\right)=\sqrt{\sum_{\mathrm{i}=1}^{6} B_{\mathrm{i}} \cdot U^{2}\left(y_{\mathrm{i}}\right)}
$$

where $B_{\mathrm{i}}=\frac{\partial V_{\text {tot }}}{\partial y_{1}}$ is the partial derivative with respect to argument $y_{\mathrm{i}}$ of the function (2) - the sensitivity coefficient; $U\left(y_{\mathrm{i}}\right)$ is $B$ type standard uncertainty of argument $y_{\mathrm{i}}$ measurement, $y_{1}=\tau_{1}, y_{2}=V_{\mathrm{c}, \gamma}, y_{3}=\tau_{\text {tot }}$, $y_{4}=\tau_{\mathrm{c}, \gamma}, y_{5}=V_{\mathrm{c}, \gamma+1}, y_{6}=\tau_{\mathrm{c}, \gamma+1}$.

Given that the input parameters included in the model (3) are not correlated, standard total uncertainty of measurement of oil extraction from wells can be determined by the following formula

$$
U_{\mathrm{c}}\left(V_{\mathrm{n}}\right)=\sqrt{\sum_{\mathrm{i}=1}^{11} E_{\mathrm{i}} \cdot U^{2}\left(z_{\mathrm{i}}\right)},
$$

where $E_{\mathrm{i}}=\frac{\partial V_{\mathrm{n}}}{\partial z_{\mathrm{i}}}$ is the partial derivative with respect to argument $z_{\mathrm{i}}$ of the function (3) - the sensitivity coefficient; $U\left(z_{\mathrm{i}}\right)$ is $B$ type standard uncertainty of argument $z_{\mathrm{i}}$ measurement, $z_{1}=\tau_{1}, z_{2}=V_{\mathrm{c}, \gamma}, z_{3}=\tau_{\text {tot }}$, $z_{4}=\tau_{\mathrm{c}, \gamma}, z_{5}=V_{\mathrm{c}, \gamma+1}, z_{6}=\tau_{\mathrm{c}, \gamma+1}, z_{7}=V_{\mathrm{c}, \gamma^{\prime}}, z_{8}=\tau_{\mathrm{sec}}$, $z_{9}=\tau_{\mathrm{c}, \gamma^{\prime}}, z_{10}=V_{\mathrm{c}, \gamma^{\prime}+1}, z_{11}=\tau_{\mathrm{c}, \gamma^{\prime}+1}$.

Taking into account the registration of the input parameters (arguments) $\tau_{1}, \tau_{\text {tot }}, \tau_{\mathrm{sec}}, \tau_{\mathrm{c}, \gamma}, \tau_{\mathrm{c}, \gamma+1}, \tau_{\mathrm{c}, \gamma^{\prime}}$, and $\tau_{c, \gamma^{\prime}+1}$ included in models (2) and (3) by the timer of the program-computational-control microprocessor located in the hardware block GMD [5], it is possible to calculate their B type expanded uncertainty with a confidence probability of $99 \%$ according to the formula

$$
U(\tau)=2,58 \cdot \tau \cdot \sigma_{\tau},
$$

where $\tau$ is the nominal value of the relevant input parameter $\left(\tau_{1}, \tau_{\text {tot }}, \tau_{\mathrm{sn}}, \tau_{\mathrm{c}, \gamma}, \tau_{\mathrm{c}, \gamma+1}, \tau_{\mathrm{c}, \gamma^{\prime}}\right.$ or $\left.\tau_{\mathrm{c}, \gamma^{\prime}+1}\right) ; \sigma_{\tau}$ is its relative root mean square error.

Taking into consideration that the most coarse relative root mean square error of time of microprocessor timer [5] is $1 \cdot 10^{-4}$ [8], then for the nominal values of the input parameters $\tau_{1}=20 \mathrm{~min}=0,33$ hour, $\tau_{\text {tot }}=$ $=30,2 \mathrm{sec}, \tau_{\mathrm{sn}}=9,3 \mathrm{sec}, \tau_{\mathrm{c}, \gamma}=30,0 \mathrm{sec}, \tau_{\mathrm{c}, \gamma+1}=30,5 \mathrm{sec}$, $\tau_{\mathrm{c}, \gamma^{\prime}}=9,0 \mathrm{sec}, \tau_{\mathrm{c}, \gamma^{\prime}+1}=9,5 \mathrm{sec}[6]$, in determining the standard uncertainties of type B of their measurements using formula (15) the following results were obtained: $U\left(\tau_{1}\right)=51,6 \cdot 10^{-4} \mathrm{~min} ; U\left(\tau_{\text {tot }}\right)=77,916 \cdot 10^{-4} \mathrm{sec}$; $U\left(\tau_{\mathrm{sn}}\right)=23,994 \cdot 10^{-4} \mathrm{sec} ; \quad U\left(\tau_{\mathrm{c}, \gamma}\right)=77,4 \cdot 10^{-4} \mathrm{sec} ;$ $U\left(\tau_{\mathrm{c}, \gamma+1}\right)=78,69 \cdot 10^{-4} \mathrm{sec} ; \quad U\left(\tau_{\mathrm{c}, \gamma^{\prime}}\right)=23,22 \cdot 10^{-4} \mathrm{sec} ;$ $U\left(\tau_{\mathrm{c}, \gamma^{\prime}+1}\right)=24,51 \cdot 10^{-4} \mathrm{sec}$.

If we take into account that the input parameters $V_{\mathrm{c}, \gamma}, V_{\mathrm{c}, \gamma+1}, V_{\mathrm{c}, \gamma^{\prime}}, V_{\mathrm{c}, \gamma^{\prime}+1}$ included in the models (2) and (3) are the volumes of the liquid (separator capacity) filled from the bottom of GMD separator to the corresponding heights of $h_{\gamma}\left(\tau_{\mathrm{c}, \gamma}\right), h_{\gamma+1}\left(\tau_{\mathrm{c}, \gamma+1}\right), h_{\gamma^{\prime}}\left(\tau_{\mathrm{c}, \gamma^{\prime}}\right)$

\begin{tabular}{|c|c|c|}
\hline \multirow{2}{*}{$\begin{array}{l}\text { Input } \\
\text { pa- } \\
\text { rame- } \\
\text { ter } y_{\mathrm{i}}\end{array}$} & \multicolumn{2}{|l|}{ Sensitivity ratio $B_{i}$} \\
\hline & Calculation formula & $\begin{array}{l}\text { Nu- } \\
\text { merical } \\
\text { value }\end{array}$ \\
\hline 1 & 2 & 3 \\
\hline$\tau_{1}$ & $-\frac{24}{\tau_{1}^{2}} \cdot\left[V_{\mathrm{c}, \gamma}+\left(\tau_{\mathrm{tot}}-\tau_{\mathrm{c}, \gamma}\right) \cdot \frac{V_{\mathrm{c}, \gamma+1}-V_{\mathrm{c}, \gamma}}{\tau_{\mathrm{c}, \gamma+1}-\tau_{\mathrm{c}, \gamma}}\right]$ & $-133,92$ \\
\hline$V_{\mathrm{c}, \gamma}$ & $\frac{24}{\tau_{1}} \cdot\left(1-\frac{\tau_{\mathrm{tot}}-\tau_{\mathrm{c}, \gamma}}{\tau_{\mathrm{c}, \gamma+1}-\tau_{\mathrm{c}, \gamma}}\right)$ & 43,64 \\
\hline $\mathrm{T}_{\text {tot }}$ & $\frac{24}{\tau_{1}} \cdot \frac{\left(V_{\mathrm{c}, \gamma+1}-V_{\mathrm{c}, \gamma}\right)}{\left(\tau_{\mathrm{c}, \gamma+1}-\tau_{\mathrm{c}, \gamma}\right)}$ & 1,46 \\
\hline$\tau_{c, \gamma}$ & $\frac{24}{\tau_{1}} \cdot \frac{\left(\tau_{\mathrm{tot}}-\tau_{\mathrm{c}, \gamma+1}\right)}{\left(\tau_{\mathrm{c}, \gamma+1}-\tau_{\mathrm{c}, \gamma}\right)^{2}} \cdot\left(V_{\mathrm{c}, \gamma+1}-V_{\mathrm{c}, \gamma}\right)$ & $-0,29$ \\
\hline$V_{\mathrm{c}, \gamma+1}$ & $\frac{24}{\tau_{1}} \cdot \frac{\tau_{\mathrm{tot}}-\tau_{\mathrm{c}, \gamma}}{\tau_{\mathrm{c}, \gamma+1}-\tau_{\mathrm{c}, \gamma}}$ & 29,09 \\
\hline$\tau_{\mathrm{c}, \gamma+1}$ & $-\frac{24}{\tau_{1}} \cdot \frac{\left(\tau_{\mathrm{tot}}-\tau_{\mathrm{c}, \gamma}\right)}{\left(\tau_{\mathrm{c}, \gamma+1}-\tau_{\mathrm{c}, \gamma}\right)^{2}} \cdot\left(V_{\mathrm{c}, \gamma+1}-V_{\mathrm{c}, \gamma}\right)$ & $-0,58$ \\
\hline
\end{tabular}
and $h_{\gamma^{\prime}+1}\left(\tau_{\mathrm{c}, \gamma^{\prime}+1}\right)$, then it is possible to calculate the $B$

Table 2. Calculation of sensitivity ratios $B_{\text {i }}$ 
Table 3. Calculation of sensitivity ratios $E_{\mathrm{i}}$

\begin{tabular}{|c|c|c|}
\hline \multirow[b]{2}{*}{$\begin{array}{l}\text { Input } \\
\text { para- } \\
\text { meter } \\
z_{\mathrm{i}}\end{array}$} & \multicolumn{2}{|l|}{ Sensitivity ratios $E_{\mathrm{i}}$} \\
\hline & Calculation formula & $\begin{array}{l}\mathrm{Nu}- \\
\text { me- } \\
\text { rical } \\
\text { value }\end{array}$ \\
\hline 1 & 2 & 3 \\
\hline$\tau_{1}$ & $\begin{array}{l}\frac{24}{\tau_{1}^{2}} \cdot\left\{\left[V_{\mathrm{c}, \gamma^{\prime}}+\left(\tau_{\mathrm{tot}}-\tau_{\mathrm{c}, \gamma}\right) \cdot \frac{V_{\mathrm{c}, \gamma+1}-V_{\mathrm{c}, \gamma}}{\tau_{\mathrm{c}, \gamma+1}-\tau_{\mathrm{c}, \gamma}}\right]-\right. \\
\left.-\left[V_{\mathrm{c}, \gamma^{\prime}}+\left(\tau_{\mathrm{sn}}-\tau_{\mathrm{c}, \gamma^{\prime}}\right) \cdot \frac{V_{\mathrm{c}, \gamma^{\prime}+1}-V_{\mathrm{c}, \gamma^{\prime}}}{\tau_{\mathrm{c}, \gamma^{\prime}+1}-\tau_{\mathrm{c}, \gamma^{\prime}}}\right]\right\}\end{array}$ & $-86,97$ \\
\hline$V_{\mathrm{c}, \gamma}$ & $\frac{24}{\tau_{1}} \cdot\left(1-\frac{\tau_{\mathrm{tot}}-\tau_{\mathrm{c}, \gamma}}{\tau_{\mathrm{c}, \gamma+1}-\tau_{\mathrm{c}, \gamma}}\right)$ & 43,64 \\
\hline $\mathrm{T}_{\text {tot }}$ & $\frac{24}{\tau_{1}} \cdot \frac{\left(V_{c, \gamma+1}-V_{c, \gamma}\right)}{\left(\tau_{c, \gamma+1}-\tau_{c, \gamma}\right)}$ & 1,46 \\
\hline$\tau_{c, \gamma}$ & $\frac{24}{\tau_{1}} \cdot \frac{\left(\tau_{\mathrm{tot}}-\tau_{\mathrm{c}, \gamma+1}\right)}{\left(\tau_{\mathrm{c}, \gamma+1}-\tau_{\mathrm{c}, \gamma}\right)^{2}} \cdot\left(V_{\mathrm{c}, \gamma+1}-V_{\mathrm{c}, \gamma}\right)$ & $-0,29$ \\
\hline$V_{\mathrm{c}, \gamma+1}$ & $\frac{24}{\tau_{1}} \cdot \frac{\tau_{\mathrm{tot}}-\tau_{\mathrm{c}, \gamma}}{\tau_{\mathrm{c}, \gamma+1}-\tau_{\mathrm{c}, \gamma}}$ & 29,09 \\
\hline$\tau_{c, \gamma+1}$ & $-\frac{24}{\tau_{1}} \cdot \frac{\left(\tau_{\mathrm{tot}}-\tau_{\mathrm{c}, \gamma}\right)}{\left(\tau_{\mathrm{c}, \gamma+1}-\tau_{\mathrm{c}, \gamma}\right)^{2}} \cdot\left(V_{\mathrm{c}, \gamma+1}-V_{\mathrm{c}, \gamma}\right)$ & $-0,58$ \\
\hline$V_{\mathrm{c}, \gamma^{\prime}}$ & $\frac{24}{\tau_{1}} \cdot\left(1-\frac{\tau_{\mathrm{sn}}-\tau_{\mathrm{c}, \gamma^{\prime}}}{\tau_{\mathrm{c}, \gamma^{\prime}+1}-\tau_{\mathrm{c}, \gamma^{\prime}}}\right)$ & 29,09 \\
\hline$\tau_{\mathrm{sn}}$ & $\frac{24}{\tau_{1}} \cdot \frac{\left(V_{c, \gamma^{\prime}+1}-V_{c, \gamma^{\prime}}\right)}{\left(\tau_{c, \gamma^{\prime}+1}-\tau_{c, \gamma^{\prime}}\right)}$ & 1,33 \\
\hline$\tau_{\mathrm{c}, \gamma^{\prime}}$ & $-\frac{24}{\tau_{1}} \cdot \frac{\left(\tau_{\mathrm{sn}}-\tau_{\mathrm{c}, \gamma^{\prime}+1}\right)}{\left(\tau_{\mathrm{c}, \gamma^{\prime}+1}-\tau_{\mathrm{c}, \gamma^{\prime}}\right)^{2}} \cdot\left(V_{\mathrm{c}, \gamma^{\prime}+1}-V_{\mathrm{c}, \gamma^{\prime}}\right)$ & $-0,27$ \\
\hline$V_{\mathrm{c}, \gamma^{\prime}+1}$ & $\frac{24}{\tau_{1}} \cdot \frac{\left(\tau_{\mathrm{sn}}-\tau_{\mathrm{c}, \gamma^{\prime}}\right)}{\left(\tau_{\mathrm{c}, \gamma^{\prime}+1}-\tau_{\mathrm{c}, \gamma^{\prime}}\right)}$ & 43,64 \\
\hline$\tau_{c, \gamma^{\prime}+1}$ & $-\frac{24}{\tau_{1}} \cdot \frac{\left(\tau_{\mathrm{sn}}-\tau_{\mathrm{c}, \gamma^{\prime}}\right)}{\left(\tau_{\mathrm{c}, \gamma^{\prime}+1}-\tau_{\mathrm{c}, \gamma^{\prime}}\right)^{2}} \cdot\left(V_{\mathrm{c}, \gamma^{\prime}+1}-V_{\mathrm{c}, \gamma^{\prime}}\right)$ & $-0,40$ \\
\hline
\end{tabular}

type standard uncertainty of their measurement with the probability confidence of $99 \%$ by the following formula

$$
U\left(V_{\mathrm{c}}\right)=2,58 \cdot V_{\mathrm{c}} \cdot \sigma_{\mathrm{V}_{\mathrm{c}}} / 100 \% .
$$

It should be noted that the volumetric calibration of GDM separator was carried out by the metal reference measuring tanks of the 1st echelon - "gauges" (reference tanks) [9]. Therefore, the root mean square of the separator calibration - the measurement of the capacity is $\sigma_{\mathrm{V}_{\mathrm{c}}}=0,025 \%$ [9]. In the levelling table of separator abovementioned nominal values of $\tau_{c, \gamma}$, $\tau_{\mathrm{c}, \gamma+1}, \tau_{\mathrm{c}, \gamma^{\prime}}, \tau_{\mathrm{c}, \gamma^{\prime}+1}$, taking into the account that $V_{\mathrm{c}, \gamma}=$ $=0,60366 \mathrm{~m}^{3} ; V_{\mathrm{c}, \gamma+1}=0,61366 \mathrm{~m}^{3} ; V_{\mathrm{c}, \gamma^{\prime}}=0,20753 \mathrm{~m}^{3}$ and $V_{c, \gamma^{\prime}+1}=0,21669 \mathrm{~m}^{3}[6]$, the measurement results obtained from the calculation of the $B$ type standard uncertainties (16) are the following: $U\left(V_{c, \gamma}\right)=$ $=0,000389 \mathrm{~m}^{3} ; \quad U\left(V_{\mathrm{c}, \gamma+1}\right)=0,000396 \mathrm{~m}^{3} ; U\left(V_{\mathrm{c}, \gamma}\right)=$ $=0,0001349 \mathrm{~m}^{3} ; U\left(V_{\mathrm{c}, \gamma^{\prime}+1}\right)=0,0001398 \mathrm{~m}^{3}$.

Tables 2 and 3 show the formulas for calculating the sensitivity coefficients $B_{\mathrm{i}}$ and $E_{\mathrm{i}}$, determined, respectively, on the basis of models (2) and (3) and the calculated numerical values necessary for the numerical estimation of the standard combined uncertainties of the production rate for total liquid and oil.

Substituting the values in Table 2 and certain values of the standard uncertainties of type $B$ of the input parameters included into the model (2) into expression (13), the calculated value of the total standard uncertainty of the production rate measurement for the total liquid $U_{\mathrm{c}}\left(V_{\text {tot }}\right)=0,6914 \mathrm{~m}^{3} /$ day. If we assume that the measurement of the production rate of one well that is filled into the separator in one day by "Trap" type GDM is carried out on an average of 5 times, then taking into account that the coverage factor $k_{\mathrm{cf}}^{\prime}$ $=2,87$ [4] at $0,95 \%$ confidence level and degree of freedom $v_{\mathrm{s}}=4$, the expanded uncertainty of the well production rate measurement for the total fluid will be $U_{\mathrm{V}_{\text {tot }}}=k_{\mathrm{cf}}^{\prime} \cdot U_{\mathrm{c}}\left(V_{\text {tot }}\right)=2,87 \cdot 0,6914=1,9843 \mathrm{~m}^{3} /$ day.

If ${ }^{\text {to }}$ we calculate the total oil well production value by writing the nominal value of the input parameters in the model (2), then we will get $V_{\text {tot }}=44,19 \mathrm{~m}^{3} /$ day.

If we substitute in formula (14) the given values in Table 3 and the determined values of the standard type B uncertainties of the input parameters included in model (3), the calculated standard uncertainty of the oil production rate will be $U_{\mathrm{c}}\left(V_{\mathrm{n}}\right)=0,4493 \mathrm{~m}^{3} /$ day. Similar to the determination of expanded uncertainty in the measurement of the production rate for the total fluid, the expanded uncertainty in the measurement of oil production rate will be $U_{\mathrm{V}_{\mathrm{n}}}=k_{\mathrm{cf}}^{\prime} U_{\mathrm{c}}\left(V_{\mathrm{n}}\right)=$ $=2,87 \cdot 0,4493=1,2895 \mathrm{~m}^{3} /$ day. Substituting the received values of the input parameters into the model (3), if we calculate the oil production rate, we obtain $V_{\mathrm{n}}=28.70 \mathrm{~m}^{3} /$ day.

\section{Conclusion}

1. Indicators of the standard specifications that are more accurate reflecting the accuracy of measurement by separate components of oil wells, or more accurately for gas, total fluid and oil production, with "Trap" type GMD have been determined.

2. Even expanded total uncertainties of measurement of gas and total fluid production complies with the requirements of operational control over the production of oil wells. Thus, for operative control over gas production expanded uncertainties of production measurements should not exceed $10 \%$ of the nominal 
value of production, and $6 \%$ of the nominal value of production on total fluid $[3,5]$.

3. Only combined standard uncertainty of oil production measurement complies with the requirements of operational control (not more than $2 \%$ of the nominal value of oil production $[3,5])$, but this does not rise the confidence probability results even to $90 \%$.
4. "Trap" type GMD should have a small number of connections of such low-productive wells (it should be noted that up to 16 wells can be connected to "Trap" type GMD [3] so that the number of observations per day can be considerably higher for each well) in order to increase the confidence probability of oil production results (so that even the expanded uncertainty of its measurement would not exceed $2 \%$ of the nominal value of the production rate).

\title{
Точнісні характеристики контролю продуктивності свердловин за загальною рідиною, нафтою і газом
}

\author{
Г.Д. Джафраров, С.М. Аббасова
}

Азербайджанський державний університет нафти та промисловості, пр-т Азадлиг, 20, 1010, Баку, Азербайджан abbasovasakina@rambler.ru

\section{Анотація}

Світова практика показує, що через неправильне управління процесом нафтовидобутку видобувається до $40 \%$ запасів нафтових родовищ, визначених під час розвідки. Однією з основних причин цього є неправильна кількісна оцінка точнісних характеристик вимірювальної інформації, отриманої при вимірюванні продуктивності нафтових свердловин, яка використовується при ухваленні управлінських рішень. Точнісна характеристика вимірювальної інформації залежить від похибки використовуваних засобів вимірювань і разом з цим від похибок, що виникають від впливу інших факторів на вимірювання. Серед оперативних вимірювальних установок дебіту нафтових свердловин найбільш надійною і раціональною є групова вимірювальна установка “Трап”.

3 огляду на те, що алгоритми контролю дебіту за газом, нафтою та загальною рідиною нафтових свердловин містять чимало періодично вимірювальних параметрів і табличних даних, на вимірювання і визначення яких впливає достатня кількість зовнішніх факторів, то як точнісну характеристику вимірювання дебіту доцільно використовувати невизначеність вимірювання дебіту за окремими компонентами. Визначення невизначеності вимірювання дебіту нафтових свердловин разом із підвищенням якості вимірювання приводить до ефективного управління експлуатацією свердловин.

Ключові слова: дебіт, вимірювання, кореляція, функція розподілу, невизначеність.

\section{Точностные характеристики контроля производительности скважин по общей жидкости, нефти и газу}

\section{Г.Д. Джафаров, С.М. Аббасова}

Азербайджанский государственный университет нефтти и промышленности, пр-m Азадлые, 20, 1010, Баку, Азербайджан abbasovasakina@rambler.ru

\section{Аннотация}

Мировая практика показывает, что из-за неправильного управления процессом нефтедобычи добывается до $40 \%$ запасов нефтяных месторождений, определенных во время разведки. Одной из основных причин этого является неправильная количественная оценка точностных характеристик измерительной информации, полученной при измерении производительности нефтяных скважин, используемая в принятии управленческих решений. Точностная характеристика измерительной информации зависит от погрешности используемых средств измерений и вместе с этим от погрешностей, возникающих от влияния других факторов на измерение. Среди оперативных измерительных установок дебита нефтяных скважин наиболее надежной и рациональной является групповая измерительная установка “Трап". 
Учитывая то, что алгоритмы контроля дебита по газу, нефти и общей жидкости нефтяных скважин содержат немало периодически измеряемых параметров и табличных данных, на измерение и определение которых влияет достаточное число внешних факторов, то в качестве точностной характеристики измерения дебита целесообразно использовать неопределенность измерения дебита по отдельным компонентам. Определение неопределенности измерения дебита нефтяных скважин наряду с повышением качества измерения приводит к эффективному управлению эксплуатацией скважин.

Ключевые слова: дебит, измерение, корреляция, функция распределения, неопределенность.

\section{References}

1. Lazovskij L.I., Smotrickij SH.M. Avtomatizaciya izmereniya produkcii neftyanyh skvazhin [Automated measurement of oil well production]. Moscow, Nedra, 1975. 167 p.

2. NTZH "Avtomatizaciya, telemekhanizaciya i svy$a z$ 'v neftyanoj promyshlennosti” [Automation, telemechanization and communication in the oil industry]. Moscow, OAO "VNIIOEHNG", 2007, no. 12 , pp. $2-5$.

3. Ustanovka zamernaya gruppovaya tipa "Trap". Tekhnicheskoe opisanie [Measuring group-plant type "Trap". Technical description]. Sumgait, NIPIneftekhimavtomat, 1990. $100 \mathrm{p}$.

4. Ocenka neopredelennosti v izmereniyah [Measurement uncertainty estimation]. Minsk, Belorusskij gosudarstvennyj institut metrologii, 2003. 49 p.

5. Dzhafarov G.D., Abbasova S.M. Algoritm funkcionirovaniya gruppovoj zamernoj ustanovki "Trap" [The algorithm of functioning of the measuring group-plant type "Trap"]. Izvestiya vysshih uchebnyh zavedenij Azerbajdzhana. Baku, 2015, no. 4, pp. 86-93.

6. Okazanie tekhnicheskoj pomoshchi pri stykovke opytnogo obrazca GZU tipa "Trap" s TM AGM MIKRO [Provision of technical assistance when aligning the prototype of "Trap" type GMD with TM AGM MICRO]. Sumgait, NIPIneftekhimavtomat, 1991. $43 \mathrm{p}$.

7. Pravila izmereniya raskhoda gazov $i$ zhidkostej standartnymi suzhayushchimi ustrojstvami [Rules for measuring the flow of gases and liquids by standard narrowing devices]. Moscow, Izdatel'stvo standartov, 1982. $320 \mathrm{p}$.

8. Artem'ev B.G., Golubev S.M. Spravochnoe posobie dlya rabotnikov metrologicheskih sluzhb [Reference manual for metrological service workers]. Moscow, Izdatel'stvo standartov, 1990. 553 p.

9. Gauzner S. I. at all. Izmerenie massy, ob'ema i plotnosti [Measurement of mass, volume and density]. Moscow, Izdatel'stvo standartov, 1982. 527 p.
10. GOST 8.570-2000. GSI. Rezervuary stal'nye vertikal'nye cilindricheskie. Metodika poverki [Steel cylindrical vertical tanks. Verification procedure]. Minsk, 2000. 64 p. (in Russian).

\section{Список литературы}

1. Лазовский Л.И., Смотрицкий Ш. М. Автоматизация измерения продукции нефтяных скважин. Москва: Недра, 1975. 167 с.

2. Автоматизация, телемеханизация и связь в нефтяной промышленности. Научно-технический журнал. Москва: ОАО “ВНИИОЭНГ", 2007, № 12. C. 2-5.

3. Установка замерная групповая типа "Трап". Техническое описание. Сумгаит: НИПИнефтехимавтомат, 1990. $100 \mathrm{c.}$

4. Оценка неопределенности в измерениях. Минск, Белорусский государственный институт метрологии, 2003. 49 с.

5. Джафаров Г.Д., Аббасова С.М. Алгоритм функционирования групповой замерной установки “Трап”. Известия высших учебных заведений Азербайджана. Баку, 2015. № 4. C. 86-93.

6. Оказание технической помощи при стыковке опытного образца ГЗУ типа “Трап” с ТМ АГМ МИКРО. Сумгаит: НИПИнефтехимавтомат, 1991. $43 \mathrm{c}$.

7. Правила измерения расхода газов и жидкостей стандартными сужающими устройствами. Москва: Изд-во стандартов, 1982. 320 с.

8. Артемьев Б. Г., Голубев С. М. Справочное пособие для работников метрологических служб. Москва: Изд-во стандартов, 1990. 553 с.

9. Гаузнер С. И. и др. Измерение массы, объема и плотности. Москва: Изд-во стандартов, 1982. $527 \mathrm{c}$.

10. ГОСТ 8.570-2000. ГСИ. Резервуары стальные вертикальные цилиндрические. Методика поверки. Минск, 2000. 64 с. 